\title{
Penerapan Teknologi Hitung Ikan pada Petani Lele di Desa Kadilangu Kec. Kangkung Kab. Kendal
}

\author{
Unang Achlison', Budi Hartono², Khoirur Rozikin³, Sulartopo 4 \\ ${ }^{1}$ Progdi Teknik Elektronika STEKOM Semarang \\ unang@stekom.ac.id \\ 2 Progdi Sistem Komputer STEKOM Semarang \\ budi@ stekom.ac.id \\ ${ }^{3}$ Progdi Sistem Komputer STEKOM Semarang \\ khoirur@stekom.ac.id \\ ${ }^{4}$ Progdi Sistem Komputer STEKOM Semarang \\ sulartopo@stekom.ac.id \\ Jl. Majapahit 605, Semarang, telp/fax : 024-6717201-02
}

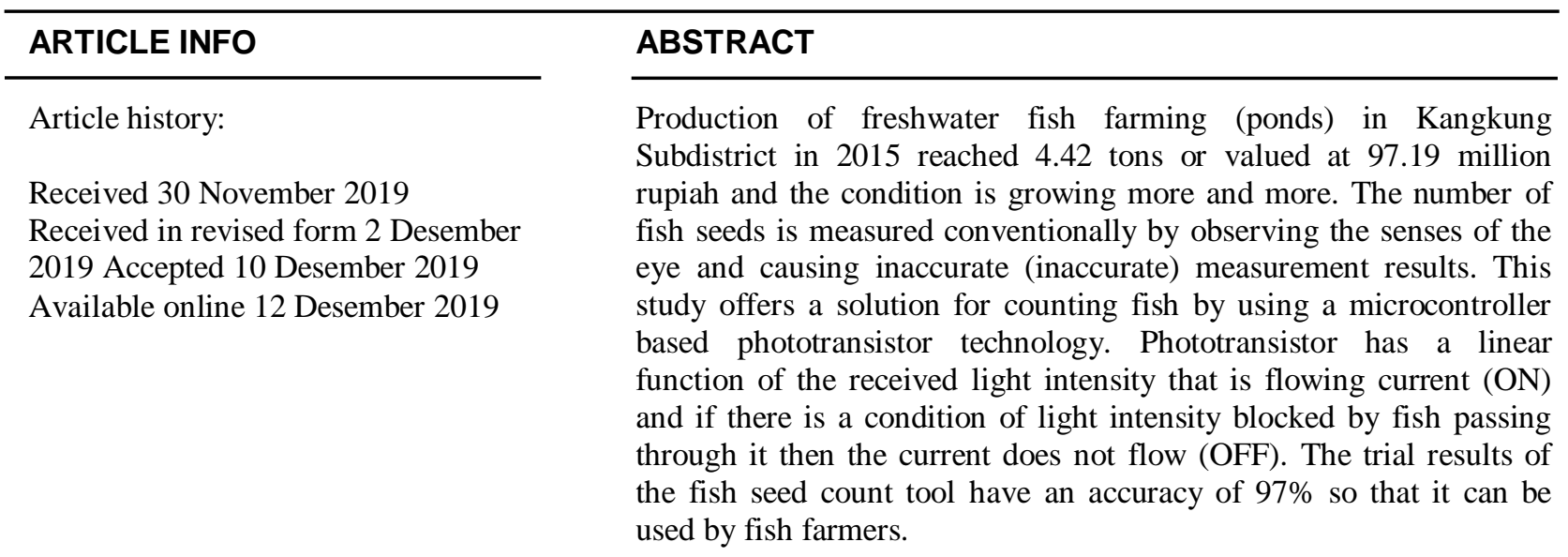

Keywords: counting fish, phototransistor, fish farmers

\section{A. PENDAHULUAN}

Secara geografis, kecamatan Kangkung di Kab. Kendal mempunyai wilayah sebelah Utara berbatasan dengan Laut Jawa. Sektor perikanan merupakan salah satu upaya meningkatkan perekonomian yang dilakukan oleh masyarakat di Desa Kadilangu Kec. Kangkung Kab. Kendal. Sektor perikanan yang dilakukan seperti budidaya ikan air tawar (kolam) dan budidaya ikan air payau (tambak). Produksi budidaya ikan air tawar (kolam) di Kecamatan Kangkung pada tahun 2015 mencapai 4,42 ton atau senilai 97,19 juta rupiah dan kondisi tersebut semakin tahun semakin berkembang. Peta wilayah kecamatan Kangkung ditunjukkan seperti pada gambar 1. 
ELKOM, Vol.12, No.2, Desember 2019, pp. 50 - 58

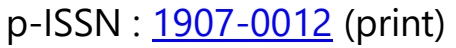

e-ISSN : 2714-5417 (online)

http://jurnal.stekom.ac.id/index.php/home

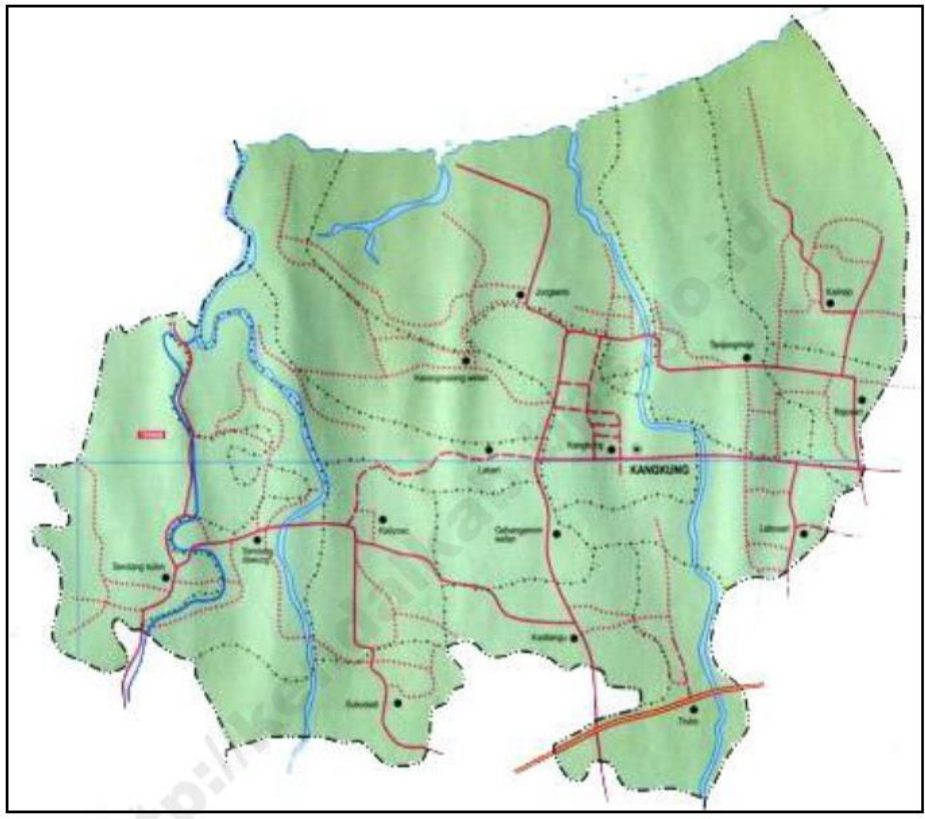

Sumber: BPS Kabupaten Kendal

Gambar 1. Peta wilayah kecamatan Kangkung

Kelompok budidaya benih ikan lele beroperasi dalam suatu rantai pasok pangan untuk memenuhi kebutuhan kelompok pembesaran ikan lele. Kelompok budidaya ikan lele "Mandiri" menjual benih ikan lele kepada budidaya ikan lele kelompok lain untuk dibesarkan dan selanjutnya kelompok pembesaran ikan lele menjual ke konsumen. Sektor perikanan yang dilakukan oleh masyarakat ditunjukkan seperti pada gambar 2.

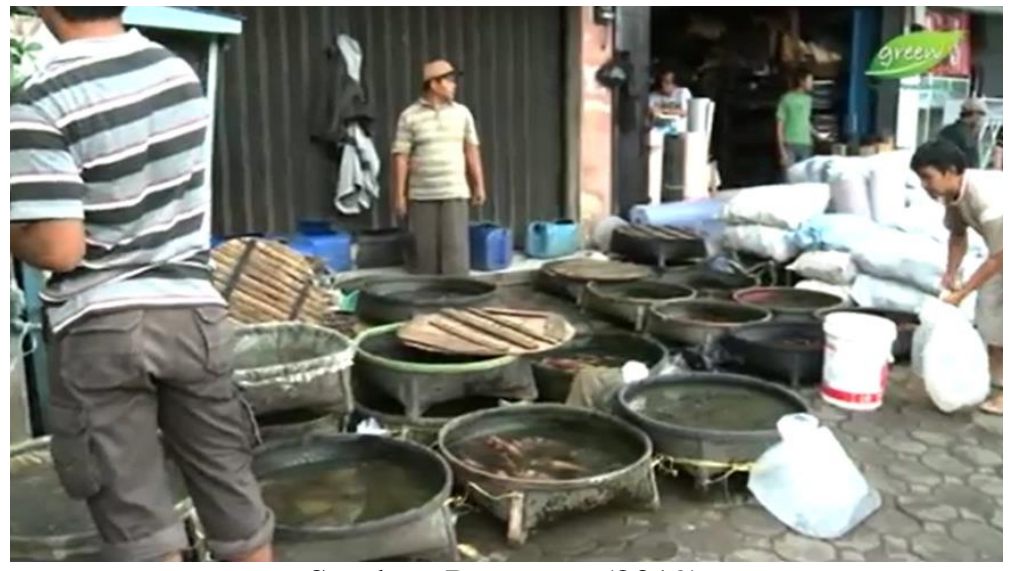

Sumber: Purwanto (2019)

Gambar 2. Perdagangan Ikan

Kelompok budidaya ikan lele "Mandiri" beralamat di Kadilangu RT.04 RW.01, Kec. Kangkung, Kab. Kendal. Kelompok budidaya ikan lele "Mandiri" menjual benih ikan lele kepada budidaya ikan lele kelompok lain dengan cara menghitung jumlah benih ikan terlebih. Cara menghitung benih ikan lele umumnya dengan memakai takaran, yaitu dengan memakai sendok dan dihitung perekor hingga memenuhi takaran kecil. Takaran ini menjadi tolok ukur untuk jumlah kelipannya seperti ditunjukkan pada gambar 3. 


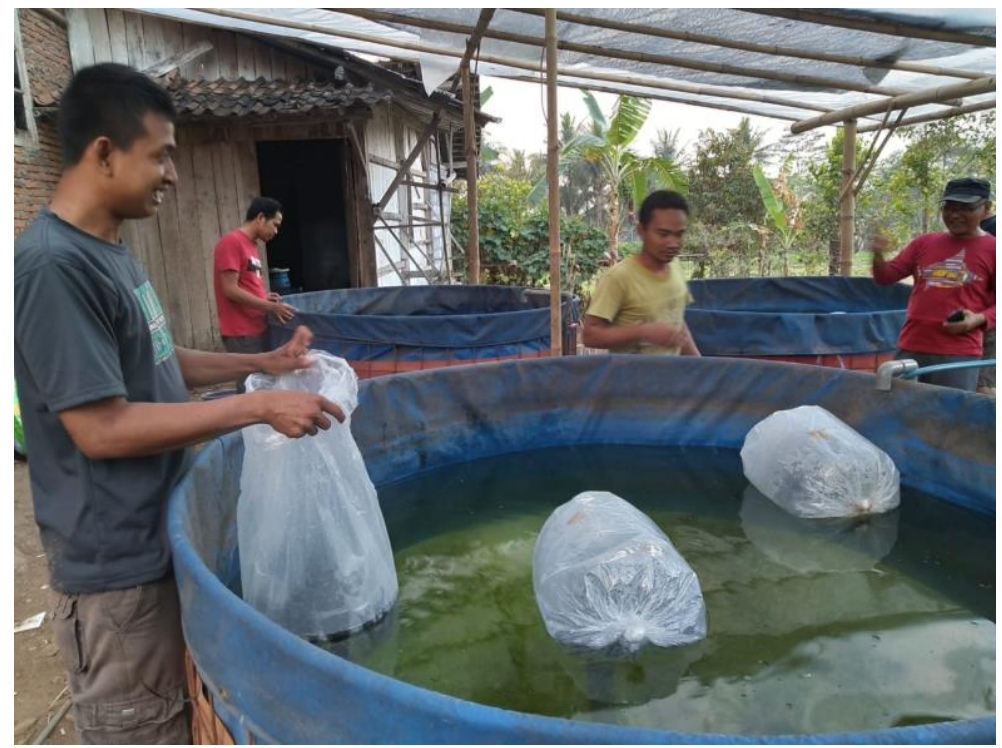

Sumber: UPR Mandiri

Gambar 3. Penghitungan jumlah benih ikan dengan cara konvensional

Penghitungan benih ikan lele secara konvensional menimbulkan permasalahan yaitu hasil hitung tidak tepat. Hitungan jumlah ikan yang tepat sangat menentukan kepercayaan antara Penjual dan Pembeli. Kelompok budidaya ikan lele "Mandiri" melakukan pencatatan hasil produksi namun sering kali tidak ada pencatatan jumlah produksi.

Kelompok budidaya ikan lele "Mandiri" melakukan penjualan atas pesanan dari kelompok pembesaran ikan lele lain di kab. Kendal dan sekitarnya seperti ditunjukkan pada gambar 4.

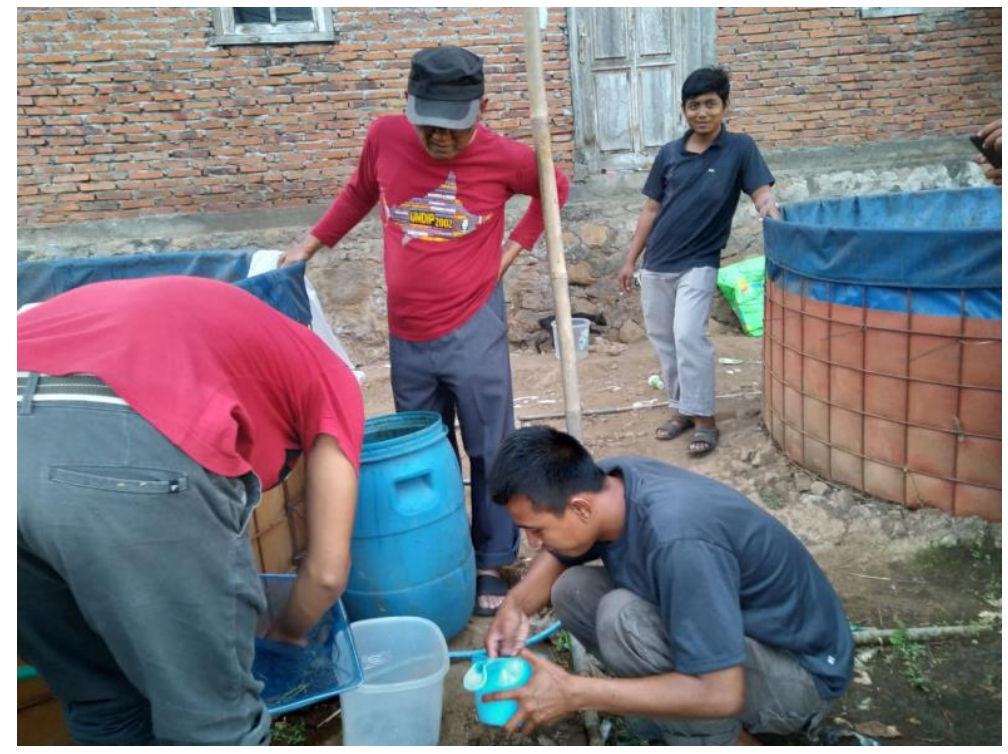

Sumber: UPR Mandiri

Gambar 4. Penjualan atas pesanan dari kelompok lain di kab. Kendal dan sekitarnya

Budidaya ikan air tawar (kolam) yang dilakukan kelompok budidaya ikan lele "Mandiri" sudah menjadi tempat percontohan pembenihan oleh Dinas Perikanan Kab. Kendal sehingga kelompok budidaya ikan lele "Mandiri" menjadi Mitra dalam program Penelitian Terapan ini. 
ELKOM, Vol.12, No.2, Desember 2019, pp. 50 - 58

p-ISSN : $\underline{1907-0012}$ (print)

e-ISSN : 2714-5417 (online)

http://jurnal.stekom.ac.id/index.php/home

\section{Rumusan Masalah}

a. Bagaimana membuat alat penghitung benih ikan yang cocok untuk benih ikan yang mempunyai ukuran kecil (pipa transparan berdiameter $1 \mathrm{~cm}$ )?

b. Bagaimana metoda yang digunakan agar air keruh dan gelembung udara yang melewati pipa transparan tidak menyebabkan kesalahan hasil hitung benih ikan?

\section{Tujuan Penelitian}

a. Membuat alat penghitung benih ikan yang tidak menyebabkan kesalahan hasil hitung ikan.

b. Membuat alat berbasis Microcontroller untuk mengolah input data dari sensor benih ikan sehingga menjadi hasil perhitungan jumlah ikan secara otomatis.

\section{B. DASAR TEORI}

1. Phototransistor

Phototransistor adalah merupakan sebuah transistor yang akan saturasi pada saat menerima sinar infra merah dan cut off pada saat tidak ada sinar infra merah. IR Module adalah sebuah rangkaian yang terdiri dari sebuah phototransistor dan filter yang terbentuk dalam satu modul di mana collector dari phototransistor adalah merupakan output dari modul ini. Pada saat phototransistor cut off maka tidak terjadi aliran arus dari collector menuju ke emitter sehingga collector yang merupakan output dari IR Module akan berkondisi high. Apabila phototransistor saturasi maka arus mengalir dari collector ke emitter dan output dari IR Module akan berkondisi low.
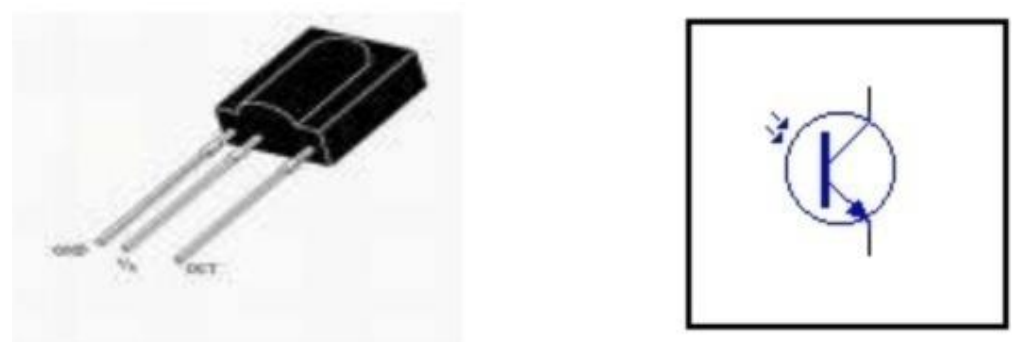

Gambar 5. Sensor Phototransistor

(Sumber : www.vishay.com)

Simbol suatu phototransistor pada gambar 5 terlihat bahwa basis dalam keadaan terbuka. Ini merupakan cara yang biasa untuk mengoperasikan suatu phototransistor. Tingkat sensitivitas cahayanya dapat dikendalikan melalui tahanan basis yang variabel (basereturn transistor), tetapi basis biasanya dibiarkan terbuka untuk mendapatkan sensitivitas yang maksimum untuk diberi cahaya. Rangkaian ini berfungsi sebagai sensor penerima cahaya infra merah yang dipancarka oleh rangkaian LED sumber cahaya infra merah. Rangkaian ini mempunyai komponen utama adalah foto transistor sebagai penerima cahaya dari LED infra merah. Foto transistor ini sudah dilengkapi dengan rangkaian band pass filter yang hanya melewatkan frekuensi antara $20 \mathrm{kHz}$ sampai $60 \mathrm{kHz}$ (Vishay Semiconductors, 2012).

Sinar Infra merah adalah gelombang elektromagnetik yang tidak dapat ditangkap mata, dengan panjang gelombang antara $0,78 \mathrm{~m}$ sampai $1 \mathrm{~mm}$. Infra merah mulai dari sinar yang dapat tertangkap mata sampai pada sinar yang kasat (tak tampak) mata (gelombang mikro). Energi Sinar adalah sebuah kemampuan atau usaha untuk memindahkan elektron dari satu lintasan ke lintasan lainnya, satuannya adalah Joule. Besarnya energi yang dimiliki oleh masing-masing cahaya saat menuju kepermukaan sensor dapat dihitung dengan menggunakan persamaan 2 dan hasilnya diperlihatkan pada tabel 1. 
Tabel 1. Data Energi Sinar yang dipancarkan

\begin{tabular}{|c|c|c|c|c|}
\hline \multirow[b]{2}{*}{$\begin{array}{l}\text { Sumber } \\
\text { Cahaya }\end{array}$} & \multicolumn{3}{|c|}{ Parameter yang di ketahui } & \multirow[b]{2}{*}{ Energi (Joule) } \\
\hline & $\begin{array}{l}\text { Tetapan } \\
\text { Planck }\end{array}$ & $\begin{array}{c}\text { Kecepatan } \\
\text { Cahaya (C) }\end{array}$ & $\begin{array}{c}\text { Panjang } \\
\text { Gelombang } \\
\text { (nano meter) }\end{array}$ & \\
\hline Laser & $6,626 \times 10^{-34}$ & $3.10^{8}$ & $532 \sim 638$ & $6,626.10^{-31}$ \\
\hline Infra Merah & $6,626 \times 10^{-34}$ & $3.10^{8}$ & 830 & $6,626.10^{-22}$ \\
\hline
\end{tabular}

Sumber: Amir D (2014); Minarni, Saktioto, Gita Lestari (2013)

Data pada tabel 1 dapat disimpulkan bahwa energi yang dimiliki cahaya inframerah jauh lebih besar dibanding energi yang dimiliki oleh cahaya laser. Nilai energi secara berturut-turut sebesar $6,626.10^{-22}$ Joule dan $6,626.10^{-31}$ Joule.

2. Microcontroller AT89S51

Menurut Djoko Tri Hastono (2009), Microcontroller AT89C51 mempunyai 40 pin yang sesuai dengan Microcontroller 8031 dan memiliki susunan pin seperti Gambar 6.
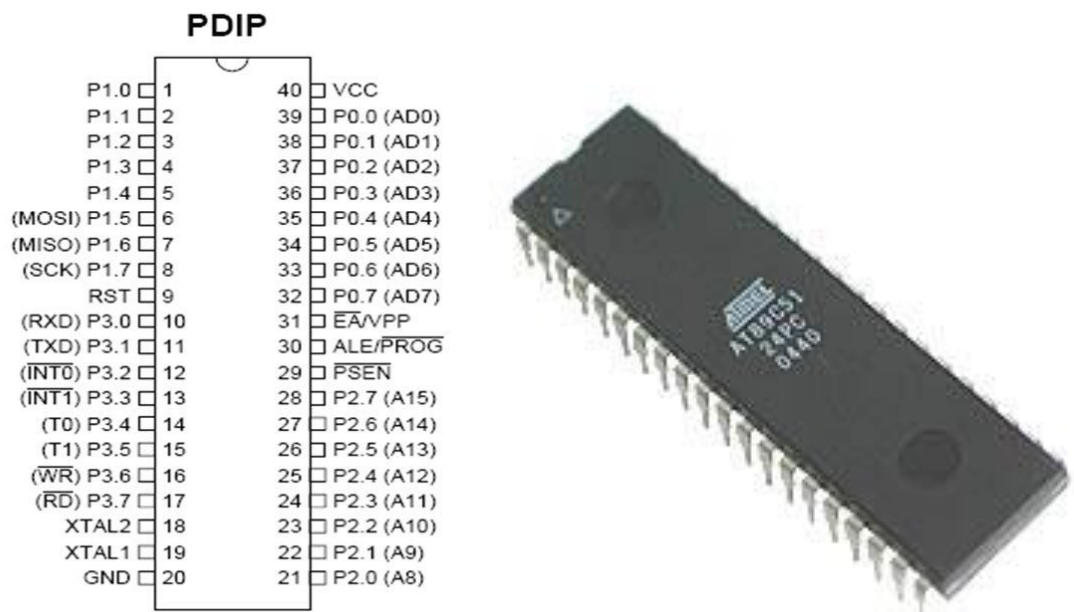

Gambar 6. Microcontroller AT89S51

(Sumber : www.forumsains.com)

Microcontroller AT89C51 mempunyai 4 port untuk I/O data dan tersedia pula akumulator, register, Ram, stack pointer, Aritmetic Logic Unit (ALU), pengunci (latch), 8 bit data bus dan memiliki 4 Kbyte flash Erasable and Programmable Read Only Memory (EPROM).

Sistem minimum Microcontroller AT89S51 mempunyai 40 pin, 32 pin diantaranya adalah kaki untuk keperluan port paralel. Setiap port paralel terdiri dari 8 pin, dengan demikian 32 pin tersebut membentuk 4 buah port paralel, yang masing-masing dikenal dengan port 0 , port 1 , port 2 , port 3 . Nomer dari masing-masing jalur (pin) dari port paralel mulai dari 0 sampai 7. Pada Port 3 untuk pin pertama yaitu port P3.0 dan pin terakhir yaitu P3.7. 
ELKOM, Vol.12, No.2, Desember 2019, pp. 50 - 58

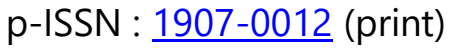

e-ISSN : 2714-5417 (online)

http://jurnal.stekom.ac.id/index.php/home

3. Benih Ikan

Benih adalah anak ikan yang memiliki bentuk morfologi tubuh sudah definitif seperti induknya. Benih berbeda dengan induknya dalam ukuran dan tingkah laku reproduksinya saja. Perilaku makan ikan herbivora sudah mulai tampak pada stadia benih, padahal pada stadia larva masih bersifat karnivora atau predatory stage (Effendi, 2004). Menurut Suseno (2000), penyediaan benih yang bermutu baik dalam jumlah cukup dan berkelanjutan merupakan faktor paling penting dalam upaya pengembangan budidaya ikan konsumsi. Satuan produksi pembenihan ikan adalah jumlah atau populasi (ekor). Satuan ini biasanya diiyatakan sebagai ekor / siklus produksi, ekor / volume bak, atau ekor / bobot (jumlah) induk.

Ukuran benih dinyatakan dalam panjang seperti $\mathrm{cm}$. Sebagai contoh untuk ukuran benih ikan lele ditampilkan pada gambar 7 .

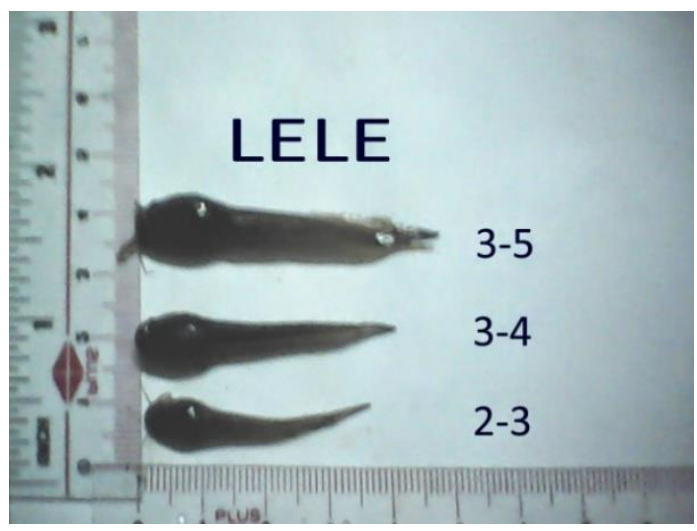

Gambar 7. Ukuran Benih Ikan Lele

(Sumber: http://www.gerailele.com/p/bibit-lele.html)

Sebagai contoh, benih mas dan kerapu umumnya dinyatakan dalam $\mathrm{cm}$ (misalnya benih ukuran 2$3 \mathrm{~cm}, 3-5 \mathrm{~cm}, 7-9 \mathrm{~cm}$, dan sebagainya). Seringkali ukuran benih dinyatakan secara kualitatif berdasarkan kesepakatanyang berlaku dan diketahui bersama (Effendi, 2004).

\section{DESAIN PENELITIAN}

1. Analisa Kebutuhan Produk

1) Studi Lapangan

Merupakan langkah awal yang bertujuan untuk memperoleh data yang dibutuhkan dalam tahap analisa. Pada tahap studi lapangan ini dilakukan dengan dua cara:

a. Pengamatan

Memantau para petani ikan menghitung jumlah benih ikan hasil pemuliaan sebelum di jual ke pasaran. Cara menghitung benih umumnya secara manual dengan memakai sendok.

b. Observasi

Melakukan observasi secara langsung dan mencatat data secara sitematis mengenai ukuran benih ikan yang diperjual belikan yaitu panjang $3 \mathrm{~cm}$ hingga $5 \mathrm{~cm}$.

c. Wawancara

Melakukan wawancara ditempat penelitian untuk memperoleh data dengan cara mengajukan beberapa pertanyaan kepada petani ikan di desa Siwarak Kota Ungaran.

2) Studi literatur

Merupakan kegiatan mengumpulkan data-data berupa teori pendukung dari sistem yang akan dibuat dan berhubungan dengan alat sensor mendeteksi kehadiran ikan. 
2. Pengembangan Produk

Desain Rancang Bangun Alat Penghitung Benih Ikan mencakup pembuatan sensor ikan yang tidak tergantung intensitas berkas cahaya yang diterima. Block diagram Alat Hitung Benih Ikan ditunjukkan seperti pada gambar 8.

(a). Bak Pengisian (filling vessel)

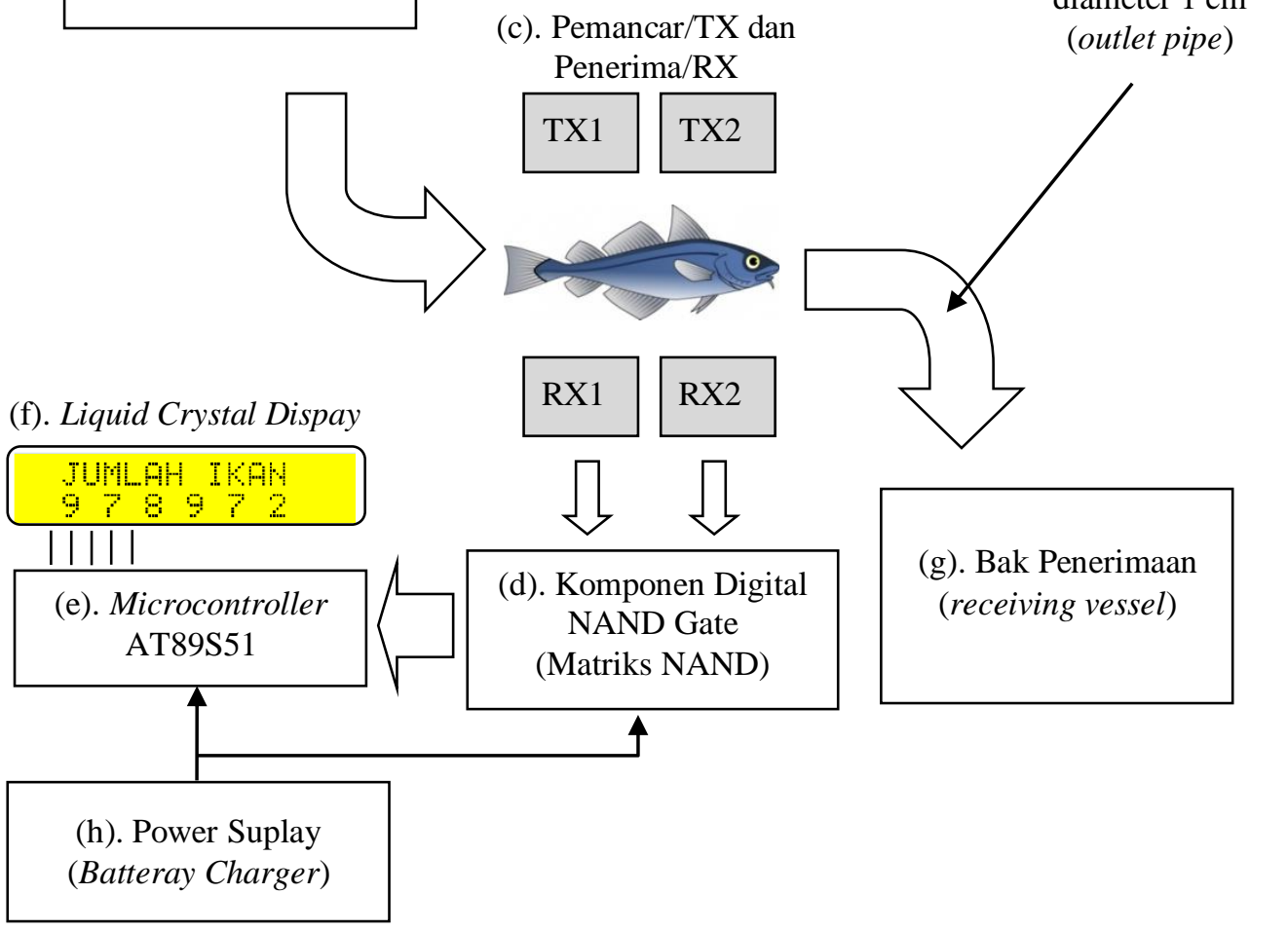

Gambar 8. Block Diagram Alat Hitung Benih Ikan

Penjelasan diagram Alat Hitung Benih Ikan sebagai berikut:

a) Bak pengisian (filling vessel) sebagai sarana Input dan digunakan untuk memasukkan air dan ikan.

b) Pipa transparan berdiameter $1 \mathrm{~cm}$ (outlet pipe) sebagai media untuk menyalurkan ikan.

c) Sensor Ikan menggunakan pemancar (TX) Infra Merah untuk menuju penerima (RX) yang berada dibalik pipa transparan.

d) Microcontroller akan menghitung jumlah benih ikan yang dimasukkan kedalam alat tersebut secara efisien, akurat dan cepat bila dibandingkan dengan perhitungan secara manual.

e) Liquid Crystal Display (display) sebagai sarana tampilan / monitor dan digunakan oleh Microcontroller AT89S51 untuk menampilkan data hasil hitung ikan.

f) Bak penerimaan (receiving vessel) sebagai sarana Output dan digunakan untuk mengeluarkan air dan ikan.

g) Power Suplay

h) Sumber tegangan Alat Hitung Ikan menggunakan transformator AC 220V menjadi $12 \mathrm{~V}$ dan menggunakan IC LM7805 menjadi 5V. 
ELKOM, Vol.12, No.2, Desember 2019, pp. 50 - 58

p-ISSN : $\underline{1907-0012}$ (print)

e-ISSN : 2714-5417 (online)

http://jurnal.stekom.ac.id/index.php/home

\section{HASIL DAN PEMBAHASAN}

\section{Alat Penghitung Benih Ikan}

Ikan yang akan dihitung terlebih dahulu dimasukkan ke dalam bak pengisian (filling vessel) untuk dialirkan melalui pipa penyaluran (outlet pipe). Bak pengisian (filling vessel) dan pipa penyaluran (outlet pipe). Microcontroller kemudian menggunakan Liquid Crystal Display untuk menampilkan data hasil hitung ikan. Alat Penghitung Benih Ikan ditunjukkan seperti pada gambar 9.

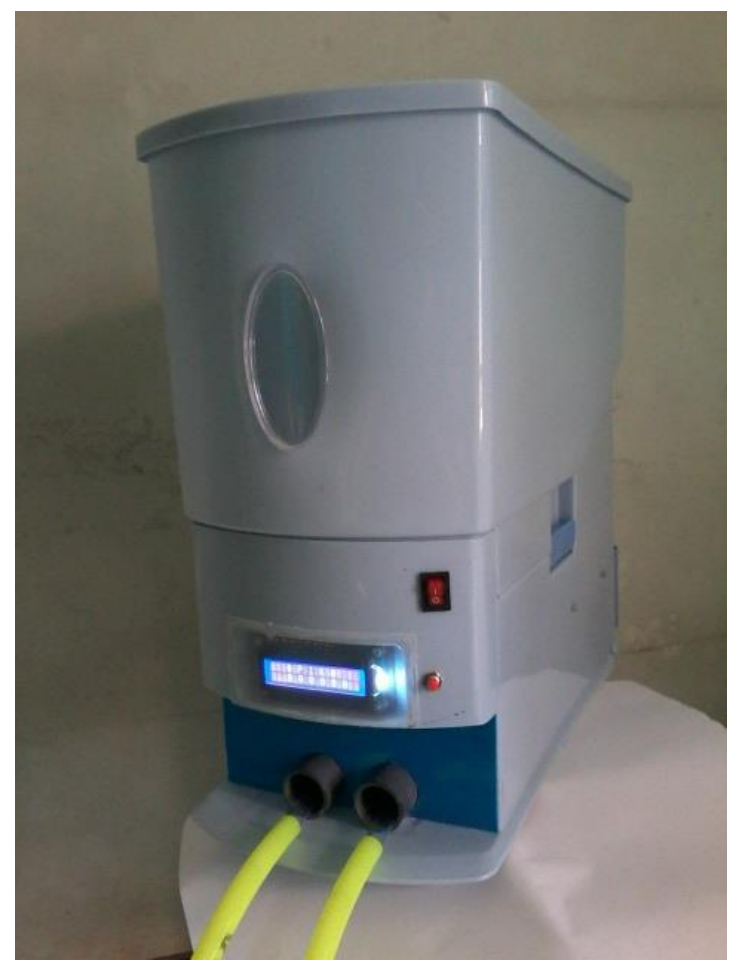

Gambar 9: Alat Hitung Ikan

\section{Uji Coba Alat}

Petani ikan lele "Mandiri" beralamat di Kadilangu RT.04 RW.01, Kec. Kangkung, Kab. Kendal menentukan jumlah benih ikan menggunakan cara manual yaitu ikan bersama air ditentukan takaran terlebih dahulu menggunakan timbangan misal 0,01 kilogram akan berisi berapa jumlah benih ikan dengan menghitung benih ikan secara manual.

Dari Jumlah yang diperoleh akan dilakukan hal yang sama untuk setiap kelipatan jumlah benih ikan. Kondisi ini dapat disimpulkan bahwa petani ikan melakukan proses penghitungan jumlah benih ikan secara tidak efisien. Hal ini disebabkan karena pengamatan mengguakan indra mata pada benih ikan sangat dipengaruhi oleh tingkat ketelitian seseorang dan besar kemungkinan hasil hitung ikan terjadi kesalahan.

Akurasi hasil penghitungan ikan yang dilakukan oleh Widagdo Purbowaskito (2014) yaitu menghitung ikan ukuran besar menggunakan pipa berdiameter $1,8 \mathrm{~cm}$ atau $3 / 4$ inci dan mempunyai akurasi hasil penghitungan ikan yaitu $91.2 \%$ atau mempunyai deviasi (penyimpangan) yaitu $8,8 \%$ dari jumlah semestinya.

Uji coba alat Penghitung Benih Ikan dilakukan dengan cara eksperimen menghitung benih ikan ukuran 3 hingga $5 \mathrm{~cm}$ yang dilewatkan melalui pipa berdiameter $1 \mathrm{~cm}$ atau $2 / 5$ inci dan kemudian membandingkan hasil hitung benih ikan terhadap jumlah semestinya (hasil hitung cara manual) untuk menentukan deviasi (penyimpangan), sebagai berikut: 
a) Apabila hasil hitung ikan lele mempunyai deviasi (penyimpangan) lebih besar dari $10 \%$ dari jumlah semestinya maka penggunaan alat penghitung benih ikan lele tidak efektif.

b) Apabila hasil hitung ikan lele mempunyai deviasi (penyimpangan) lebih kecil dari $10 \%$ dari jumlah semestinya maka penggunaan alat penghitung benih ikan lele bisa diterima untuk digunakan Petani Ikan lele.

Uji coba alat Penghitung Benih Ikan dilakukan kepada petani ikan lele "Mandiri" beralamat di Kadilangu RT.04 RW.01, Kec. Kangkung, Kab. Kendal. Hasil uji coba alat hitung benih ikan kepada petani ikan ditunjukkan pada tabel 2.

Tabel 2. Hasil uji coba alat hitung benih ikan kepada petani ikan

\begin{tabular}{|c|l|l|l|}
\hline \multirow{2}{*}{ No. } & \multicolumn{1}{|c|}{ Instrumen } & \multicolumn{1}{|c|}{ Pengujian 1 } & \multicolumn{1}{c|}{ Pengujian 2 } \\
\cline { 3 - 4 } & & \multicolumn{1}{|c|}{ Hasil } & \multicolumn{1}{c|}{ Hasil } \\
\hline 1. & hitung Manual & 350 ekor & 375 ekor \\
\hline 2. & hitung Alat & 340 ekor & 364 ekor \\
\hline 3. & $\begin{array}{l}\text { deviasi } \\
\text { (penyimpangan) }\end{array}$ & 10 ekor & 11 ekor \\
\hline 4. & tingkat deviasi & $(10 / 350) \times 100 \%=3 \%$ & $(11 / 375) \times 100 \%=2,93 \%$ \\
\hline
\end{tabular}

\section{E. SIMPULAN DAN SARAN}

1. Simpulan

Dari penelitian ini dapat ditarik kesimpulan, sebagai berikut :

1) Alat Penghitung Jumlah Benih Ikan menggunakan sensor phototransistor penerima cahaya infra red dengan frekuensi $20 \mathrm{KHz}$ sebagai media untuk mendeteksi ikan yang dilewatkan pada pipa transparan berdiameter $1 \mathrm{~cm}$.

2) Berdasarkan maka hasil uji coba alat hitung benih ikan mempunyai deviasi (penyimpangan) rata-rata 2,9\% terhadap jumlah semestinya atau mempunyai Akurasi hasil penghitungan ikan mencapai $97 \%$.

2. Saran

Kapasitas penghitung benih ikan dibawah seribu maka tingkat akurasi alat penghitung benih ikan ini mempunyai deviasi (penyimpangan) rata-rata 2,9\% terhadap penghitungan manual oleh petani benih ikan.

\section{DAFTAR PUSTAKA}

Amir D. 2014. Analisis Kecepatan Reaksi Sensor Terhadap Gelombang Cahaya Infra Merah Dan Laser. Jurnal Litek (ISSN: 1693-8097) Volume 11 Nomor 1, Maret 2014: hal. 8-12

BPS Kabupaten Kendal. 2018. Kangkung dalam angka 2017. Koordinator Statistik Kecamatan Kangkung. Koordinator Statistik Kecamatan Kangkung

Djoko Tri Hastono. 2009. Sistem Pengendali dan Pengukur Suhu Pada Mesin Penetas Telur berbasis Mikrokontroler At89S51. Graduates thesis, Universitas Negeri Semarang

Effendi, I. 2004. Pengantar Akuakultur . Penebar Swadaya. Jakarta

Minarni, Saktioto, Gita Lestari. 2013. Prosiding Semirata FMIPA Universitas Lampung. Semirata 2013 FMIPA Unila, halaman 167

Purwanto. 2019. "Implementasi metoda matrix berbasis diskrit untuk mendeteksi obyek bergerak di dalam air". Jurnal Elektronika dan Komputer, Vol 12, No.1, 2019

Suseno. 2000. Pengelolaan Usaha Pembenihan Ikan Mas. Penebar Swadaya. Jakarta

Vishay Semiconductors. 2012. Document Number: 81665 Rev. 1.4, 28 Mar 2012

Widagdo Purbowaskito. 2014. Rancang Bangun Alat Penghitung Benih Ikan Menggunakan Sensor Optik Fototransistor Berbasis Mikrokontroler ATMEL ATMEGA8. Universitas Gajah Mada, Yogjakarta, Jawa tengah 